\title{
Dynamics and Edge Effect of an Atlantic Forest Fragment in Brazil
}

\author{
Poliana Gabriella Araújo Mendes ${ }^{1}$, Maria Amanda Menezes Silva ${ }^{1}$, \\ Tassiane Novacosque Feitosa Guerra ${ }^{2}$, Ana Carolina Borges Lins-e-Silva ${ }^{1}$, \\ Airton de Deus Cysneiros Cavalcanti ${ }^{1}$, Everardo Valadares de Sá Barretto Sampaio ${ }^{3}$, \\ Maria Jesus Nogueira Rodal ${ }^{1}$

\begin{abstract}
${ }^{1}$ Departamento de Biologia, Universidade Federal Rural de Pernambuco - UFPE, Recife/PE, Brasil
${ }^{2}$ Unidades de Conservação, Agência Estadual de Meio Ambiente, Recife/PE, Brasil
\end{abstract} \\ ${ }^{3}$ Departamento de Energia Nuclear, Universidade Federal de Pernambuco - UFPE, Recife/PE, Brasil
}

\begin{abstract}
The woody plants in an edge area formed approximately 35 years ago in an Atlantic Forest fragment in northeastern Brazil were examined, and three environments defined: edge, intermediate, and interior. Canopy tree densities and basal areas were found to be similar in all three environments, and also similar to previous published studies in the same region; species richness was greatest at the forest edge. The understory showed greater species richness in the forest interior, but greater diversity and equitability in the intermediate environment. Understory environments close to the forest edge demonstrated larger stem diameters than in the forest interior, although at lesser densities and with smaller total basal areas. Our results indicated the existence of distinct patterns in canopy and understory that most likely reflect differences in the response times of these two vegetation layers, with the understory being more sensitive to alterations in environmental structure.
\end{abstract}

Keywords: canopy, tropical rain forest, understory.

\section{Dinâmica e Efeito de Borda de um Fragmento de Floresta Atlântica no Brasil}

\section{RESUMO}

As plantas lenhosas foram examinadas em uma borda formada há aproximadamente 35 anos em um fragmento de Floresta Atlântica. Foram examinados três ambientes: borda, intermediário e interior. A densidade e a área basal de árvores foram semelhantes entre os três ambientes e também próximas à de outros estudos publicados com dados da mesma região. A riqueza de espécies foi maior na borda. Sub-bosque mostrou grande riqueza de espécies no interior da floresta, mas grande diversidade e equitabilidade no ambiente intermediário. Os sub-bosques dos ambientes próximos à borda da floresta possuem mais indivíduos com diâmetros maiores que no interior, embora com densidade e área basal menores. Os resultados indicam a existência de padrões distintos para o dossel e para o sub-bosque, que provavelmente resultaram dos diferentes tempos de resposta desses dois estratos da vegetação, com o sub-bosque mostrando-se mais sensível a alterações na estrutura ambiental.

Palavras-chave: dossel, floresta tropical úmida, sub-bosque. 


\section{INTRODUCTION}

Neotropical forests demonstrate exceptional species richness as well as high levels of endemism, but they have been subjected to accentuated destruction and alterations due to human activities since colonial times (Myers et al., 2000). These habitat losses have had the direct effect of exposing remnant areas to novel environment conditions, reducing population sizes as well as alterating migration and dispersal patterns that contribute to biodiversity losses (Murcia, 1995; Cadenasso et al., 2003).

Edge and area effects are the most important factors driving alterations in fragmented communities (Fahrig, 2003; Harper et al., 2005). Numerous studies have shown that the long-term maintenance of animal and plant populations in fragmented areas will depend on the existence of networks of fragments functioning as sources and sinks (Laurance et al., 2002; Ries et al., 2004; Nascimento \& Laurance, 2006) - and there will be a tendency for local extinctions if these conditions cannot be maintained. Hanski \& Ovaskainen (2002) demonstrated that many species respond rapidly to the environmental changes resulting from fragmentation, while others show much slower responses. From the community perspective, Tilman et al. (1994) used the term "extinction debt" to refer to situations following habitat loss in which suitable conditions for the survival and/or reproduction of some species no longer exist, although they can continue to survive within the community due to lag times in responding to those environment changes.

As an example of this type of delayed response, Metzger (1998) reported that species richness in the understory of an Atlantic Forest area in southeastern Brazil appeared to be more sensitive to alterations in environmental structure than canopy tree richness, as the latter took much longer to express significant changes in richness or diversity. According to Metzger et al. (2009), the mechanisms involved in these delayed responses are still poorly understood, and it will be necessary to examine in detail the long-term evolution of landscape structures and species-dependent plant responses in order to address this subject.

Within the context of fragmentation, there is a general consensus that analyses of population dynamics and succession (sensu Pickett et al., 2008) will aid in determining how ecological processes (expressed as fluctuations of the values of mortality and recruitment and the growth of individuals) and disturbances influence the spatial and temporal patterns of plant populations (Lundberg \& Ingvarsson, 1998; Lewis et al., 2004) - aspects that are fundamental to the analysis of fragmentation effects.

Regarding the speed of forest structure recuperation, a number of studies have indicated that there is an initial recuperation of tree density followed by basal area, species richness, and species composition recoveries (Finegan, 1996; Guariguata \& Ostertag, 2001; Letcher \& Chazdon, 2009). Forest edges tend to become structurally more open in the first years following fragmentation - and therefore more permeable to heat, light, and wind fluxes (Gascon et al., 2000; Laurance et al., 2002). Over time, however, the edges gradually begins to seal through the proliferation of colonizing trees and vines, and these plants will have a substantial influence on the microclimate (Camargo \& Kapos, 1995; Didham \& Lawton, 1999) as well as on the structure and dynamics of the local vegetation (Laurance et al., 1998; Mesquita et al., 1999; Marín et al., 2007). Edge sealing continues with the passage of more time, although the precise speed of this process is still being debated (Harper et al., 2005).

As edge sealing progresses, there may be disassociations between structural and floristic responses to those border influences, and tropical forests may demonstrate different recuperation responses depending on which plant parameters are analyzed. The present work examined a forest edge formed approximately 35 years ago in a 91 hectare fragment of Atlantic Forest in northeastern Brazil and its influence on the structure, composition, and population dynamics (2005 and 2008) of the canopy and understory vegetation. Previous studies of edge effects have led us to expect the canopy and understory areas closest to the forest edge to demonstrate structural and floristic parameters most strongly influenced by edge effects.

\section{MATERIAL AND METHODS}

Study area - The forest fragment studied here is located on the grounds of the Usina São José (USJ), situated in the municipality of Igarassu, Pernambuco State, Brazil. This sugar producing farm ("Usina") has 
106 forest fragments in the Atlantic Forest domain (IBGE, 2012) that cover a total area of approximately of 6660 ha; $44.2 \%$ of these fragments have areas of between 10 and 100 ha (Trindade et al., 2008). The farm retains $24 \%$ of its original forest cover, with the most recent clearing having occurred in the mid 1970's when the federal government encouraged sugarcane crops to boost alcohol production (Kimmel et al., 2008; Trindade et al., 2008).

The forest fragment examined is known locally as the "Mata de BR" (7'47'14"- $7^{\circ} 48^{\prime} 06^{\prime \prime}$ 'S and $34^{\circ} 56^{\prime} 39^{\prime \prime}$ $34^{\circ} 55^{\prime} 60^{\prime \prime} \mathrm{W}$ ), with altitude ranging from 20 to $85 \mathrm{~m}$ above sea level. Examinations of aerial photographs from the 1960s, 70 s and 80 s confirmed that the fragment edges were established 35 years before the present study began and no signs of any fires or recent tree cutting were observed in the forest.

The hot and humid regional climate is classified as As' in the Köppen system (Kottek et al., 2006), with a mean annual rainfall of $1687 \mathrm{~mm}$ (concentrated between March and August) and a mean annual temperature of $24.9^{\circ} \mathrm{C}$ (data collected for the years 1998 to 2007 at the USJ meteorological station). The predominant winds in the area come from the southwest. This forest fragment grows on a generally flat tableland formation (on the Barreiras geological formation, dating from the Plio-Pleistocene age) that is defined by deep and narrow valleys.

Study design and data analysis - Initial surveys of the canopy and the woody understory of the "Mata de BR" forest were undertaken in the second half of 2005 by Lins-e-Silva (2010) and Gomes et al. (2009) respectively. These authors defined the "edge" as extending up to $50 \mathrm{~m}$ into the fragment interior, followed by an "intermediate" environment extending from 50 to $100 \mathrm{~m}$ farther in, with the "interior" forest environment being more than $150 \mathrm{~m}$ from the forest edge. The edge and intermediate environments were sampled using a methodology modified from Oosterhoorn \& Kappelle (2000) that consisted of laying out two $10 \times 100 \mathrm{~m}$ transects perpendicular to (and starting at) the forest edge. These transects were then divided into a sequence of 10 contiguous $10 \times 10 \mathrm{~m}$ plots $(0.1 \mathrm{ha})$. The forest interior was sampled using ten $10 \times 10 \mathrm{~m}$ plots in a single $20 \times 50 \mathrm{~m}$ block $(0.1 \mathrm{ha})$. Transects were laid out with a southwestern orientation in order to exclude variables related to the orientation of the sun; ground inclinations were similar in all plots.
The canopy trees were sampled in each plot considering all live individuals with trunk diameters $>$ $4.77 \mathrm{~cm}$ at $1.3 \mathrm{~m}$ above ground level (DBH). To sample the woody understory plants, $5 \times 5 \mathrm{~m}$ sub-plots were installed in the upper left corners of the canopy plots, considering all plants with stem diameter at ground level (DGL) between 0.96 and $4.77 \mathrm{~cm}$.

A second survey was undertaken during the second half of 2008 that measured the heights and diameters of all of the live individuals originally sampled in 2005 , as well as new individuals that had reached the threshold inclusion criteria by 2008 . The individuals that were alive in 2005 but could not be found in the 2008 survey were recorded as dead. The diameters of all canopy and understory individuals that surpassed the inclusion criteria used previously were measured and included in the 2008 survey; the heights of the woody understory plants were also recorded. The plants that fell between the two inclusion categories $(>4.77 \mathrm{~cm}$ DGL and $<4.77 \mathrm{~cm} \mathrm{DBH)}$ in 2005 were measured and then added to the woody understory to avoid any discontinuity between the two classes.

The specimens collected were identified using the technical literature, by comparisons with material deposited in the Dárdano de Andrade Lima Herbarium at the Instituto Agronômico de Pernambuco, and by consulting specialists. These collections were subsequently deposited in the Geraldo Mariz Herbarium at the Universidade Federal de Pernambuco. The spelling of the species and the authors' names were verified by consulting the site www.ipni.org.

We collected $500 \mathrm{~g}$ samples from the superficial soil layer $(0-20 \mathrm{~cm})$ at the center of each $10 \times 10 \mathrm{~m}$ plot for both chemical and textural analyses using standard protocols (EMBRAPA, 1997). The variables examined were: soil $\mathrm{pH}$ in suspension, the levels of phosphorous $(\mathrm{P})$, potassium $\left(\mathrm{K}^{+}\right)$, calcium $\left(\mathrm{Ca}^{2+}\right)$, magnesium $\left(\mathrm{Mg}^{2+}\right)$, and aluminum $\left(\mathrm{Al}^{3+}\right)$, and the proportions of sand, silt, and clay.

The general parameters of density, basal area, diameter, and average heights of the communities were calculated for the two surveys (2005 and 2008); diameter histograms were prepared using $5 \mathrm{~cm}$ intervals for canopy trees and $1 \mathrm{~cm}$ intervals for understory plants; height histograms for the understory plants were elaborated using $1 \mathrm{~m}$ intervals. Vegetation structures were analyzed by calculating the absolute densities of 
the species. Species diversities (in 2005 and 2008) were analyzed using the Shannon diversity index ( $\mathrm{H}$, in nats./ ind.) and Pielou's equitability (J'). All parameter were calculated using Mata Nativa 2 software (Souza et al., 2006). Sørensen's index was used to evaluate the floristic similarities between the edge, intermediate, and interior environments.

To compare the plant physiognomies between and within the three environments and at different times (2005 and 2008) we evaluated the numbers of individuals, basal area, height and average diameter, species richness, diversity, and equitability per plot. The comparisons of the environments at the two different times were performed using the " $\mathrm{t}$ " test (unilateral) for paired samples. Comparisons between the different environments themselves were performed by first using the Kolmogorov-Smirnov test to examine data normality; data showing normal distributions were submitted to one criterion ANOVA that was complemented by the "t de Tukey" test when the ANOVA results indicted differences between the environments at a significance level of 0.05 (Zar, 1999). When the parameters did not show normality, the non-parametric Kruskal-Wallis test was employed, complemented by Dunn's test. Diameter classes were compared using the KolmogorovSmirnov test for independent samples. The chemical and physical variables of the soil were compared between the different environments using the same statistical analyses employed for vegetation structure and physiognomy. All analyses were performed using Bioestat 5.0 software (Ayres et al., 2007).

The data from 2005 and 2008 were used to calculate the recruitment rates $(\mathrm{R}=\{[(\mathrm{N} 0+\mathrm{r}) / \mathrm{N} 0] 1 / \Delta \mathrm{t}-1\} \times 100)$, mortality $(\mathrm{M}=\{1-[(\mathrm{N} 0-\mathrm{m}) / \mathrm{N} 0] 1 / \Delta \mathrm{t}\} \times 100)$, and trunk diameter growth rates $(\mathrm{RGR}=\{[(\mathrm{DAP} 1-\mathrm{DAP} 0] /$ DAP0 $] 1 / \Delta t-1\} \times 100$ ) of the plant communities in the three environments using the formula described by Welden et al. (1991) and Sheil et al. (1995), within the time interval $(\Delta t)$ of three years.

The correlations between the numbers of individuals of each species and the environmental variables in the canopy and understory plots were examined using canonic correspondence analysis. The principal matrix was composed of species abundances and secondarily by soil variables. Rare species were eliminated as recommended by Ter Braak (1995) and only species with abundances $>5$ individuals were considered. The data was log-transformed before analysis to compensate for biases caused by a few elevated values, and the analyses were performed using PC-Ord 4 software (McCune \& Mefford, 1999).

\section{RESULTS}

Canopy - The results of the canopy survey undertaken in 2008 indicated that there were no significant differences between the three forest environments. There were increases in the numbers of individuals between 2005 and 2008, with recruitment being significantly superior to deaths in all environments. The increase in basal area in the environments nearest the forest edge occurred as a function of increasing plant densities. The basal area in the interior site diminished (in spite of an increase in the absolute number of individuals there) due to the decrease in the average diameter (which was greatly influenced by the death of a very large tree - with a DBH of $22 \mathrm{~cm}$ ). The average trunk diameter in the intermediate environment did not increase between 2005 and 2008; the edge environment demonstrated a decrease in this parameter due to the inclusion of new individuals with smaller diameters (Table 1 ). Approximately $60 \%$ of the individuals (2008) in the three environments were included within the smallest diameter class $(4.77-9.77 \mathrm{~cm})$ (Table 2).

Recruitment was greater than mortality in all three environments. The two environments closest to the forest edge had approximately twice the mortality rate (0.9-0.95\%/year) of the interior environment $(0.5 \% /$ year $)$ (Table 1). The greatest recruitment rate was observed in the interior environment (3.6\%/year) while the values for the edge and intermediate environments were 2.40 and $2.74 \%$ /year respectively. All of the environments had similar trunk diameter growth rates (0.15 to $16 \mathrm{~cm} /$ year) (Table 1 ).

The edge environment had a higher number of tree species in 2008 (38) than the other environments (intermediate $=32$ and interior $=29$ ), and showed greater diversity ( $\mathrm{H}^{\prime}=3.16$ versus 2.85 and 2.80 nats/ind.). The similarities between species compositions of the three environments were low, with values ranging from 0.29 to 0.33 .

Understory - Our results demonstrated that there were notable differences between the three understory environments in 2008. The interior area was distinct 
Table 1. General parameters, dynamics, species richness, and diversity and equitability indices for the edge, intermediate, and interior environments for canopy trees ( 0.1 ha per environment) and the woody understory plants (0.025 ha per environment) in Igarassu, Pernambuco State, Brazil, for 2005 and 2008.

\begin{tabular}{|c|c|c|c|c|c|c|}
\hline \multirow[b]{2}{*}{ Parameters } & \multicolumn{2}{|c|}{ Edge } & \multicolumn{2}{|c|}{ Intermediate } & \multicolumn{2}{|c|}{ Interior } \\
\hline & 2005 & 2008 & 2005 & 2008 & 2005 & 2008 \\
\hline \multicolumn{7}{|l|}{ CANOPY } \\
\hline Numbers of individuals & $149^{\mathrm{B}}$ & $156^{\mathrm{A}}$ & 142 & 150 & $138^{\mathrm{B}}$ & $153^{\mathrm{A}}$ \\
\hline Density (ind./ha) & 1490 & 1560 & 1420 & 1500 & 1380 & 1530 \\
\hline Basal area $\left(\mathrm{m}^{2} / \mathrm{ha}\right)$ & 26.1 & 26.6 & $19.1^{\mathrm{B}}$ & $20.2^{\mathrm{A}}$ & 30.2 & 24.4 \\
\hline Average diameter $(\mathrm{cm})$ & 12.6 & 12.5 & 10.9 & 10.9 & 12.7 & 11.9 \\
\hline Number of deaths & - & 4 & - & 4 & - & 1 \\
\hline Number of recruits & - & 11 & - & 12 & - & 16 \\
\hline Mortality rate (\%/year) & - & 0.9 & - & 0.95 & - & 0.5 \\
\hline Recruitment rate (\%/year) & - & 2.4 & - & 2.74 & - & 3.6 \\
\hline Diameter growth (cm/year) & - & 0.16 & - & 0.15 & - & 0.15 \\
\hline Number of species & $36^{\mathrm{a}}$ & $38^{\mathrm{a}}$ & $30^{\mathrm{b}}$ & $32^{\mathrm{b}}$ & $28^{c}$ & $29^{\mathrm{b}}$ \\
\hline Diversity (H' nats./ind.) & $3.1^{\mathrm{a}}$ & $3.16^{\mathrm{a}}$ & $2.79^{\mathrm{b}}$ & $2.85^{\mathrm{b}}$ & $2.8^{\mathrm{b}}$ & $2.8^{\mathrm{b}}$ \\
\hline Equitability (J) & 0.87 & 0.87 & 0.82 & 0.82 & 0.84 & 0.83 \\
\hline \multicolumn{7}{|l|}{ WOODY UNDERSTORY } \\
\hline Numbers of individuals & $306^{\mathrm{Bb}}$ & $401^{\mathrm{Ab}}$ & $263^{\mathrm{Bb}}$ & $386^{\mathrm{Ab}}$ & $770^{\mathrm{Ba}}$ & $911^{\mathrm{Aa}}$ \\
\hline Density (ind/ha) & 12240 & 16040 & 10520 & 15440 & 30800 & 36440 \\
\hline Basal area $\left(\mathrm{m}^{2} / \mathrm{ha}\right)$ & $4.3^{\mathrm{Bb}}$ & $8.7^{\text {Aab }}$ & $3.7^{\mathrm{Bb}}$ & $6.3^{\mathrm{Ab}}$ & $7.4^{\mathrm{Ba}}$ & $10.4^{\mathrm{Aa}}$ \\
\hline Average diameter $(\mathrm{cm})$ & $1.81^{\mathrm{ab}}$ & $2.18^{\mathrm{a}}$ & $1.89^{\mathrm{a}}$ & $2.11^{\mathrm{a}}$ & $1.55^{\mathrm{b}}$ & $1.7^{\mathrm{b}}$ \\
\hline Average height (m) & 1.66 & 1.94 & 1.69 & 1.96 & 1.68 & 1.62 \\
\hline Number of deaths & - & 24 & - & 19 & - & 64 \\
\hline Number of recruits & - & $104+(15)$ & - & $130+(12)$ & - & $197+(8)$ \\
\hline Mortality rate (\%/year) & - & 2.7 & - & 2.5 & - & 2.8 \\
\hline Recruitment rate (\%/year) & - & 10.24 & - & 14.3 & - & 7.8 \\
\hline Diameter growth (cm/year) & - & 0.05 & - & 0.05 & - & 0.05 \\
\hline Number of species & $35^{\mathrm{b}}$ & $40^{\mathrm{b}}$ & $36^{\mathrm{b}}$ & $43^{\mathrm{b}}$ & $48^{\mathrm{a}}$ & $55^{\mathrm{a}}$ \\
\hline Diversity (H’ nats./ind.) & $2.18^{\mathrm{b}}$ & $2.23^{\mathrm{b}}$ & $2.88^{\mathrm{a}}$ & $2.8^{\mathrm{a}}$ & $2.6^{\mathrm{a}}$ & $2.65^{\mathrm{a}}$ \\
\hline Equitability (J) & 0.61 & 0.6 & 0.8 & 0.74 & 0.67 & 0.66 \\
\hline
\end{tabular}

Numbers within parentheses correspond to individuals of the diameter class not sampled in 2005; Upper case letters indicate significant statistical differences $(\mathrm{p} \leq 0.05)$ between 2005 and 2008, and lower case letters indicate significant statistical differences $(\mathrm{p} \leq 0.05)$ between edges, intermediate and interior environments in 2005 and 2008.

from the two environments nearest the forest edge (Table 1), having a greater number of individuals (36,440; versus 16,440 and 15,440 ind./ha). This larger number of individuals likewise resulted in a higher area basal (10.4; versus 8.7 and $\left.6.3 \mathrm{~m}^{2} / \mathrm{ha}\right)$ in spite of the smaller average diameters of those interior individuals (1.7; versus 2.2 and $2.1 \mathrm{~m}^{2} / \mathrm{ha}$ ). The basal area values in the two environments nearest the forest edge were found to have practically doubled in relation to those encountered in 2005 (Table 1), with the greatest proportions of individuals occurring in the smallest diameter class $(0.96-1.96 \mathrm{~cm})(\mathrm{p}<0.05)$ (Table 2).

The classes $>4.96 \mathrm{DGL}$ and $<4.77 \mathrm{DBH}$ had 35 individuals that would not have been tallied if the discontinuity of the inclusion criterion used in the 2005 survey had been maintained (refer to the Methods section). Of these 35 individuals, 19 were located in the edge environment. The intermediate and interior environments had greater numbers of individuals in the second height class (1.1 to $2 \mathrm{~m}$ ), while the greatest number of individuals in the edge environment occurred in the smallest height class ( 0.1 to $1 \mathrm{~m}$ )

Growth rates were similar in all three environments (2.5 to $2.8 \%$ ), although the interior environment had almost three times the number of individuals present in the other environments. The three environments showed similar values for trunk diameter growth (0.05 cm/year) (Table 1), and recruitment was greater than mortality in all of them. The number of recruited individuals was greater in the interior (197) 
Table 2. Number of canopy ( 0.1 ha per environment) and woody understory ( 0.025 ha) individuals in 2005 and 2008 by diameter and height class in three environments in the Mata de BR, Igarassu, Pernambuco State, Brazil.

\begin{tabular}{|c|c|c|c|c|c|c|}
\hline \multirow{3}{*}{$\begin{array}{c}\text { CANOPY } \\
\text { Class of Diameter at Breast } \\
\text { Height }(\mathrm{cm})\end{array}$} & \multicolumn{6}{|c|}{ NUMBERS of INDIVIDUALS } \\
\hline & \multicolumn{2}{|c|}{ Edge } & \multicolumn{2}{|c|}{ Intermediate } & \multicolumn{2}{|c|}{ Interior } \\
\hline & 2005 & 2008 & 2005 & 2008 & 2005 & 2008 \\
\hline 4.77-9.77 ו- & 74 & 79 & 86 & 94 & 75 & 86 \\
\hline 9.77-I14.77 & 37 & 37 & 30 & 27 & 26 & 27 \\
\hline $14.77-\mid 19.77$ & 14 & 18 & 13 & 16 & 14 & 19 \\
\hline $19.77-124.77$ & 10 & 5 & 4 & 4 & 8 & 8 \\
\hline $24.77-129.77$ & 8 & 8 & 4 & 4 & 6 & 5 \\
\hline$>29.77$ & 6 & 9 & 5 & 5 & 9 & 8 \\
\hline Total & 149 & 156 & 142 & 150 & 138 & 153 \\
\hline $\begin{array}{l}\text { WOODY UNDERSTORY } \\
\text { Class of diameter at } \\
\text { ground level }(\mathrm{cm})\end{array}$ & & & DODY & RSTO & & \\
\hline $0.96 \dashv 1.96$ & 215 & 252 & 184 & 249 & 614 & 694 \\
\hline $1.96 \dashv 2.96$ & 47 & 59 & 39 & 65 & 107 & 137 \\
\hline $2.96-3.96$ & 35 & 50 & 30 & 38 & 41 & 48 \\
\hline $3.96-4.96$ & 7 & 21 & 10 & 20 & 8 & 23 \\
\hline$>4.96 \mathrm{DGL}$ and $<4.77 \mathrm{DBH}$ & 2 & 19 & 0 & 14 & 0 & 9 \\
\hline Total & 306 & 401 & 263 & 386 & 770 & 911 \\
\hline HEIGHT CLASSES (m) & & & DODY & RSTO & & \\
\hline $0.1 \vdash-1$ & 111 & 149 & 58 & 114 & 145 & 308 \\
\hline $1.1-2$ & 127 & 130 & 143 & 139 & 435 & 354 \\
\hline $2.1-3$ & 33 & 50 & 49 & 71 & 141 & 140 \\
\hline $3.1-4$ & 12 & 17 & 8 & 26 & 39 & 68 \\
\hline $4.1-5$ & 15 & 31 & 2 & 15 & 6 & 21 \\
\hline $5.1+6$ & 3 & 16 & 2 & 9 & 3 & 14 \\
\hline$>6$ & 5 & 8 & 1 & 12 & 1 & 6 \\
\hline Total & 306 & 401 & 263 & 386 & 770 & 911 \\
\hline
\end{tabular}

than in the two environments nearest the forest edge (104 and 130 individuals in the edge and intermediate environments respectively).

The forest interior differed from the other two environments by having a greater species richness (55; versus 43 and 40 ), while diversity was greatest in the intermediate environment $\left(\mathrm{H}^{\prime}=2.8\right)$ (Table 1$)$. The Sørensen indexes were low and similar in all three environments (0.44 to 0.55$)$.

\subsection{Multivariate analyses}

Of the nine chemical and textural characteristics of the soil examined, two (silt and $\mathrm{K}^{+}$) did not show any variation among the three environments (Table 3 ) (and likewise did not demonstrate any significant correlations with the axes of the canonic correspondence analysis for the canopy or understory) and were therefore eliminated from further consideration. (Table 4).
The characteristics that composed axes 1 and 2 were not the same for the canopy and the understory. Of these, only two differed between the three environments and were inversely correlated: $\mathrm{pH}$ (which was greater in the interior site) and $\mathrm{Al}^{3+}$ (highest in the intermediate environment). The sand content of the soil samples was significantly greater in the interior environment, while clay was better represented at the edge.

Regarding the canopy, of the seven edaphic characteristics analyzed, only three demonstrated any significant correlation with the axes: $\mathrm{Al}^{3+}, \mathrm{Ca}^{2+}$ and clay content. All three had low eigenvalues $(<0.3)$, however, for both the first (0.21) and second (0.08) axes. These two axes together explained only $13.1 \%$ (axis 1, 9.6\% and axis 2, 3.5\%) of the observed variation in the data, indicating that a large part of the variance could be stochastic or could not be explained by the characteristics analyzed (Table 4). 
Table 3. Chemical and textural variables of the three environments in the Mata de BR, Igarassu, Pernambuco State, Brazil.

\begin{tabular}{|c|c|c|c|c|c|c|c|}
\hline \multirow{3}{*}{ Variables } & \multirow{3}{*}{ Edge } & \multirow{3}{*}{ Intermediate } & \multirow{3}{*}{ Interior } & \multicolumn{4}{|c|}{ Auto values } \\
\hline & & & & \multicolumn{2}{|c|}{ Canopy } & \multicolumn{2}{|c|}{$\begin{array}{c}\text { Woody } \\
\text { Understory }\end{array}$} \\
\hline & & & & 1 & 2 & 1 & 2 \\
\hline $\mathrm{pH}$ in $\mathrm{H}_{2} \mathrm{O}$ & $5 \pm 0.5 \mathrm{ab}$ & $4.7 \pm 0.1 b$ & $5.2 \pm 0.2 \mathrm{a}$ & - & - & 0.599 & -1.593 \\
\hline $\mathrm{P}-$ Mehlich $\left(\mathrm{mg} \cdot \mathrm{dm}^{-3}\right)$ & $5.4 \pm 4.8$ & $4.6 \pm 0.5$ & $3.3 \pm 1.2$ & - & - & -0.192 & -0.361 \\
\hline $\mathrm{Ca}^{2+}\left(\mathrm{cmolc}^{2} \mathrm{dm}^{-3}\right)$ & $1.4 \pm 1.4$ & $0.6 \pm 0.3$ & $0.9 \pm 0.5$ & -0.900 & -0.452 & -0.463 & -0.132 \\
\hline $\mathrm{Mg}^{2+}\left(\mathrm{cmolc} \mathrm{dm}^{-3}\right)$ & $0.9 \pm 0.7$ & $0.6 \pm 0.1$ & $0.7 \pm 0.1$ & - & - & -0.100 & 0.77 \\
\hline $\mathrm{Al}^{3+}\left(\mathrm{cmolc} \cdot \mathrm{dm}^{-3}\right)$ & $0.9 \pm 0.8 \mathrm{ab}$ & $1.2 \pm 0.2 \mathrm{a}$ & $0.4 \pm 0.2 b$ & -0.900 & -0.425 & -0.424 & -1.686 \\
\hline Sand (\%) & $64.4 \pm 1.9 b$ & $67.8 \pm 2.1 \mathrm{ab}$ & $72.8 \pm 7.7 \mathrm{a}$ & - & - & 0.040 & -0.463 \\
\hline Clay (\%) & $29.2 \pm 3.3 b$ & $27.0 \pm 2.2 \mathrm{~b}$ & $21.2 \pm 4.9 \mathrm{a}$ & -0.654 & 0.528 & -0.289 & 0.269 \\
\hline
\end{tabular}

The values are averages \pm standard deviation for 30 samples; Letters indicate statistically significant differences $(\mathrm{p} \leq 0.05)$ between the edge, intermediate and interior environments.

Table 4. Canonic correspondence analysis of the abundance of 18 canopy species distributed among thirty $10 \times 10 \mathrm{~m}$ plots, and 37 understory species distributed among thirty $5 \times 5 \mathrm{~m}$ plots, in relation to soil factors in the Mata de BR, Igarassu, Pernambuco State, Brazil. The results of the first two ordination axes are provided.

\begin{tabular}{lccccc} 
& \multicolumn{2}{c}{ Canopy } & & \multicolumn{2}{c}{ Woody Understory } \\
\cline { 2 - 3 } \cline { 5 - 6 } & $\mathbf{1}$ & $\mathbf{2}$ & $\mathbf{1}$ & $\mathbf{2}$ \\
Eingenvalues & 0.22 & 0.08 & & 0.31 & 0.14 \\
Correlation species $\times$ environment factors & 9.6 & 3.5 & & 14.0 & 6.4 \\
$\begin{array}{l}\text { Cumulative percentage variations (\%) of the species } \times \\
\text { environment factors }\end{array}$ & 9.6 & 13.0 & & 14.0 & 20.5 \\
Monte Carlo permutation tests & 0.01 & 0.14 & 0.01 & 0.03 \\
\hline
\end{tabular}

In terms of the understory, all of the seven the characteristics considered $\left(\mathrm{P}, \mathrm{pH}, \mathrm{Al}^{3+}, \mathrm{Ca}^{2+}, \mathrm{Mg}^{2+}\right.$, sand, and clay) demonstrated significant correlations with the first two axes, with eigenvalues greater than 0.3 on axis $1(0.31)$ but lower on axis $2(0.13)$. Axes 1 and 2 explained $14 \%$ and $6.4 \%$, respectively, of the variance observed for the three environments, indicating that a large fraction of the variance demonstrated by the species could not be explained by the soil characteristics analyzed. As such, and considering that both the topography and the orientations of the plots in relation to the sun were controlled for, we can assume that edge effects, associated with the time of edge formation, were the principal agents modulating the species richness and structures of the environments studied here (Table 4).

\section{DISCUSSION}

Canopy - As the edge environment in the present study (which was established approximately 35 years ago) had a density (1490-1560 ind./ha) similar to that of the interior site and was, in turn, very similar to the values reported for other general quantitative surveys undertaken in northeastern Brazil (ranging from 1471 to 1657 ind./ha) using the same basic methodology (Siqueira et al., 2001; Rocha et al., 2008; Silva et al., 2008a, b) - it can be concluded that no edge effect (sensu Harper et al., 2005) was detectable at the study site. Basal area values were likewise very similar to those reported in other surveys of lowland forest areas in the region using the same inclusion criteria (which varied from 26.8 to $30.1 \mathrm{~m}^{2} / \mathrm{ha}$ ) (Siqueira et al., 2001; Alves-Júnior et al., 2006; Silva et al., 2008b), and the species composition, species richness, and diversity of the canopy trees in the edge environment did not demonstrate marked differences from the interior environment.

Regarding the speed of forest structure recuperation, reports in the literature indicate that there is usually an initial recuperation of plant density, which is followed by the recuperation of basal area, species richness, and species composition (Finegan, 1996; Guariguata \& 
Ostertag, 2001; Letcher \& Chazdon, 2009). Our results indicated, however, that the forest edge studied here had not yet demonstrated any responses to edge effects.

Studies examining the dynamics of the different factors that act on edge and interior canopy components have been scarce, making interpretations of our results more difficult. In an attempt to address this problem, the data from the interior environment studied here were compared to other studies undertaken in mature tropical forests - as these would be expected to have grown under similar environmental conditions. The mortality rate observed in the present study $(0.5 \% /$ year) was close to the lower limits reported for humid tropical and semideciduous forests (which vary from 0.9 to $3.2 \%$ /year) (Swaine et al., 1987; Condit et al., 1992; Phillips et al., 1994; Condit et al., 1999; Oliveira-Filho et al., 2007; Laurance et al., 2009), and the recruitment rate (3.6\%/year) observed here was greater than the rates reported for other humid tropical forests (1.65 to 2.87\%/year) (Condit et al., 1999). These results suggest that the interior environment examined in the present study had been disturbed.

Understory - In relation to the woody understory, the two environments nearest the forest edge had lower densities, basal areas, and diameters. The interior site differed from the other two environments in terms of its greater species richness (55; versus 43 and 40), while diversity was greater in the intermediate environment $\left(H^{\prime}=2.8\right.$ nats/ind.) (Table 1). In terms of species composition, the Sørensen indexes of the three environments were all low and very similar - possibly due to the small sample sizes involved.

As for population dynamics, the environments nearest the forest edge demonstrated greater recruitment rates, while greater understory species richness and diversity was observed in the environments farthest from the edge.

\section{FINAL CONSIDERATIONS}

In examining the question of whether different recuperation responses to forest edge formation might be observed in terms of different phytosociological parameters, we analyzed the density, basal area, species richness, and composition of the canopy and understory plants in an Atlantic Forest fragment whose edges had been established approximately 35 years earlier. As such, it appears that only the understory was responding to edge effects - although it is important to remember that the canopy trees in the interior environment were still in their growth (not mature) phase.

\section{ACKNOWLEDGEMENTS}

The authors would like to acknowledge the support provided by the project "Sustentabilidade de remanescentes de Floresta Atlântica em Pernambuco e suas implicações para a conservação e desenvolvimento local", which is part of a scientific collaboration program between Brazil and Germany within the "Science and Technology for the Atlantic Forest" program that is financed by the Conselho Nacional de Pesquisa de Desenvolvimento Científico e Tecnológico (590039/2006-7), as well as the Usina São José S.A./ Grupo Cavalcanti Petribú for its logistical support.

\section{SUBMISSION STATUS}

Received: 31 oct., 2013

Accepted: 16 feb., 2016

\section{CORRESPONDENCE TO}

\section{Maria Jesus Nogueira Rodal}

Departamento de Biologia, Universidade Federal Rural de Pernambuco - UFPE, Rua Dom Manoel de Medeiros, s/n, Dois Irmãos, CEP 52171-900, Recife, PE, Brasil

e-mail:mrodal@terra.com.br

\section{REFERENCES}

Alves-Júnior FT, Brandão CFLS, Rocha KD, Marangon LC, Ferreira RLC. Efeito de borda na estrutura de espécies arbóreas em um fragmento de floresta ombrófila densa, Recife, PE. Revista Brasileira de Ciências Agrárias 2006; 1(1): 49-56.

Ayres M, Ayres JRM, Ayres DL. BioEstat 5.0: aplicações estatísticas nas áreas das ciências biológicas e médicas. Belém: Sociedade Civil Mamirauá; 2007.

Cadenasso ML, Pickett STA, Weathers KC, Jones CG. Framework for a theory of ecological boundaries. Bioscience 2003; 53(8): 550-558. http://dx.doi.org/10.1641/00063568(2003)053[0750:AFFATO]2.0.CO;2.

Camargo JL, Kapos V. Complex edge effects on soil moisture and microclimate in central Amazonian forest. Journal of Tropical Ecology 1995; 11(2): 205-221. http:// dx.doi.org/10.1017/S026646740000866X. 
Condit R, Ashton PS, Manokaran N, LaFrankie JV, Hubbell SP, Foster RB. Dynamics of the forest communities at Pasoh and Barro Colorado: comparing two 50-ha plots. Philosophical Transactions of the Royal Society of London. Series B, Biological Sciences 1999; 354(1391): 1739-1758. http://dx.doi.org/10.1098/rstb.1999.0517. PMid:11605618.

Condit RPS, Hubbell SP, Foster RB. Short-term dynamics of a Neotropical forest: change within limits. Bioscience 1992; 42(11): 822-828. http://dx.doi.org/10.2307/1312081.

Didham RK, Lawton JH. Edge structure determines the magnitude of changes in microclimate and vegetation structure in tropical forest fragments. Biotropica 1999; 31(1): 17-30.

Empresa Brasileira de Pesquisa Agropecuária - EMBRAPA. Manual de métodos de análises de solo. 2nd ed. Rio de Janeiro: Centro Nacional de Pesquisa de Solos; 1997.

Fahrig L. Effects of habitat fragmentation on biodiversity. Annual Review of Ecology Evolution and Systematics 2003; 34(1): 487-515. http://dx.doi.org/10.1146/annurev. ecolsys.34.011802.132419.

Finegan B. Pattern and process in Neotropical secondary rain forests: the first 100 years of succession. Trends in Ecology \& Evolution 1996; 11(3): 119-124. http://dx.doi. org/10.1016/0169-5347(96)81090-1. PMid:21237778.

Gascon C, Williamson B, Fonseca GAB. Receding forest edges and vanishing reserves. Science 2000; 288(5470): 1356-1358. http://dx.doi.org/10.1126/science.288.5470.1356. PMid:10847849.

Gomes JS, Lins e Silva ACB, Rodal MJN, Silva HCH. Estrutura do sub-bosque lenhoso em ambientes de borda e interior de dois fragmentos de Floresta Atlântica em Igarassu, Pernambuco. Rodriguésia 2009; 60(2): 295-310.

Guariguata MR, Ostertag R. Neotropical secondary forest succession: changes in structural and functional characteristics. Forest Ecology and Management 2001; 148(1): 185-206. http://dx.doi.org/10.1016/S03781127(00)00535-1.

Hanski I, Ovaskainen O. Extinction debt at extinction threshold. Conservation Biology 2002; 16(3): 666-673. http://dx.doi.org/10.1046/j.1523-1739.2002.00342.x.

Harper KA, Macdonald E, Burton PJ, Chen J, Brosofske $\mathrm{KD}$, Saunders SC et al. Edge influence on forest structure and composition in fragmented landscapes. Conservation Biology 2005; 19(3): 768-782. http://dx.doi.org/10.1111/ j.1523-1739.2005.00045.x.

Instituto Brasileiro de Geografia e Estatística - IBGE. Manual técnico da vegetação brasileira: sistema fitogeográfico, inventário das formações florestais e campestres, técnicas e manejo de coleções botânicas, procedimentos para mapeamentos. 2nd ed. Rio de Janeiro: IBGE; 2012.

Kimmel TM, Piechowski D, Gottsberger G. The history of fragmentation of the lowland Atlantic Forest of
Pernambuco, Brazil. Bioremediation. Biodiversity and Bioavailability 2008; 2(1): 4-8.

Kottek M, Grieser J, Beck C, Rudolf B, Rubel F. World map of the Köppen-Geiger climate classification updated. Meteorologische Zeitschrift 2006; 15(3): 259-263. http:// dx.doi.org/10.1127/0941-2948/2006/0130.

Laurance SGW, Laurance WF, Nascimento HEM, Andrade A, Fearnside PM, Rebello ERG et al. Long-term variation in Amazon forest dynamics. Journal of Vegetation Science 2009; 20(2): 323-333. http://dx.doi.org/10.1111/j.16541103.2009.01044.x.

Laurance WF, Ferreira LV, Merona JMR, Laurance SG, Hutchings RW, Lovejoy TE. Effects of forest fragmentation on recruitment patterns in Amazonian tree communities. Conservation Biology 1998; 12(2): 460-464. http://dx.doi. org/10.1046/j.1523-1739.1998.97175.x.

Laurance WF, Lovejoy TE, Vasconcelos HL, Bruna EM, Didham RK, Stouffer PC et al. Ecosystem decay of Amazonian forest fragments: a 22-year investigation. Conservation Biology 2002; 16(3): 605-618. http://dx.doi. org/10.1046/j.1523-1739.2002.01025.x.

Letcher SG, Chazdon RL. Rapid recovery of biomass, species richness, and species composition in a forest chronosequence in Northeastern Costa Rica. Biotropica 2009; 41(5): 608-617. http://dx.doi.org/10.1111/j.17447429.2009.00517.x.

Lewis SL, Phillips OL, Sheil D, Vinceti B, Baker TR, Brown $S$ et al. Tropical forest tree mortality, recruitment and turnover rates: calculation, interpretation and comparison when census intervals vary. Journal of Ecology 2004; 92(6): 929-944. http://dx.doi.org/10.1111/j.00220477.2004.00923.x.

Lins-e-Silva ACB. Influência da área e da heterogeneidade de habitats na diversidade vegetal em fragmentos de Floresta Atlântica [tese]. Rio de Janeiro: Universidade Federal do Rio de Janeiro; 2010.

Lundberg S, Ingvarsson P. Population dynamics of resource limited plants and their pollinators. Theoretical Population Biology 1998; 54(1): 44-49. http://dx.doi.org/10.1006/ tpbi.1997.1349. PMid:9680488.

Marín GC, Nygår R, Rivas BG, Oden PC. Stand dynamics and basal area change in a tropical dry forest reserve in Nicaragua. Forest Ecology and Management 2007; 208(1): 63-75.

McCune B, Mefford MJ. Pc-Ord. Multivariate analysis of ecological data. 4th ed. Gleneden Beach: MjM Software Design; 1999.

Mesquita R, Delamonica P, Laurance WF. Effects of surrounding vegetation on edge-related tree mortality in Amazonian forest fragments. Biological Conservation 1999; 91(2): 129-134. http://dx.doi.org/10.1016/S00063207(99)00086-5. 
Metzger JP, Martensen AC, Dixo M, Bernacci LC, Ribeiro MC, Teixeira AMG et al. Time-lag in biological responses to landscape changes in a highly dynamic Atlantic forest region. Biological Conservation 2009; 142(6): 1166-1177. http://dx.doi.org/10.1016/j.biocon.2009.01.033.

Metzger JP. Changements de la structure du paysage et richesse spécifique des fragments forestiers dans le Sud-Est du Brésil. CRACAD SCI III-VIE 1998; 321(4): 319-333.

Murcia C. Edges effects in fragmented forest: implications for conservation. Trends in Ecology \& Evolution 1995; 10(2): 58-62. http://dx.doi.org/10.1016/S0169-5347(00)88977-6. PMid:21236953.

Myers N, Mittermeier RA, Mittermeier CG, Fonseca GAB, Kent J. Biodiversity hotspots for conservation priorities. Nature 2000; 403(6772): 853-858. http://dx.doi. org/10.1038/35002501. PMid:10706275.

Nascimento HEM, Laurance WF. Efeitos de área e de borda sobre a estrutura florestal em fragmentos de floresta de terra-firme após 13-17 anos de isolamento. Acta Amazonica 2006; 36(2): 183-192. http://dx.doi. org/10.1590/S0044-59672006000200008.

Oliveira-Filho AT, Carvalho WAC, Machado ELM, Higuchi P, Appolinário V, Castro GC et al. Dinâmica da comunidade e populações arbóreas da borda e interior de um remanescente florestal na Serra da Mantiqueira, Minas Gerais, em um intervalo de cinco anos (1999-2004). Revista Brasileira de Botânica 2007; 30(1): 149-161. http:// dx.doi.org/10.1590/S0100-84042007000100015.

Oosterhoorn M, Kappelle M. Vegetation structure and composition along an interior-edge-exterior gradient in a Costa Rican montane cloud forest. Forest Ecology and Management 2000; 126(3): 291-307. http://dx.doi. org/10.1016/S0378-1127(99)00101-2.

Phillips OL, Hall P, Gentry AH, Sawyer SA, Vásquez R. Dynamics and species richness of tropical rain forests. Ecology 1994; 91(7): 2805-2809. PMid:11607468.

Pickett STA, Cadenasso ML, Meiners SJ. Ever since Clements: from succession to vegetation dynamics and understanding to intervention. Applied Vegetation Science 2008; 12(1): 9-21. http://dx.doi.org/10.1111/j.1654109X.2009.01019.x.

Ries L, Fletcher RJJ Jr, Battin J, Sisk TD. Ecological responses to habitat edges: mechanisms, models and variability explained. Annual Review of Ecology Evolution and Systematics 2004; 35(1): 491-522. http://dx.doi. org/10.1146/annurev.ecolsys.35.112202.130148.
Rocha KD, Chaves LFC, Marangon LC, Lins e Silva ACB. Caracterização da vegetação arbórea adulta em um fragmento de floresta atlântica, Igarassu, PE. Revista Brasileira de Ciências Agrárias 2008; 3(1): 35-41. http:// dx.doi.org/10.5039/agraria.v3i1a219.

Sheil D, Burslem DFRP, Alder D. The interpretation and misinterpretation of mortality rate measures. Journal of Ecology 1995; 83(2): 331-333. http://dx.doi. org/10.2307/2261571.

Silva AG, Sá-e-Silva IMM, Rodal MJN, Lins e Silva ACB. Influence of edge and topography on canopy and subcanopy structure of an Atlantic Forest Fragment in Igarassu, Pernambuco State, Brazil. Bioremediation, Biodiversity and Bioavailability 2008a; 2(1): 41-46.

Silva HCH, Lins-e-Silva ACB, Gomes JS, Rodal MJN. The effect of internal and external edges on vegetation physiognomy and structure in a remnant of Atlantic lowland rainforest in Brazil. Bioremediation, Biodiversity and Bioavailability 2008b; 2(1): 47-55.

Siqueira DR, Rodal MJN, Lins-e-Silva ACB, Melo AL. Physiognomy, structure, and floristics in an area of Atlantic Forest in Northeast Brazil. In: Gottsberger G, Liede S, editors. Life forms and dynamics in tropical forest. Berlin: Jim Cramer; 2001.

Souza VC, Silva GF, Chichorro JF, Caracciolo RL. Mata Nativa 2: manual do usuário. Viçosa: Cientec; 2006.

Swaine MD, Lieberman D, Putz FE. The dynamics of tree populations in tropical forest: a review. Journal of Tropical Ecology 1987; 3(4): 359-366.

Ter Braak CJF. Ordination. In: Ongman RHG, Ter Braak CJF, Van Tongeren OFR, editors. Data analysis in community and landscape ecology. Cambrigde: Cambridge University Press; 1995.

Tilman D, May RM, Lehman CL, Nowak MA. Habitat destruction and the extinction debt. Nature 1994; 371(6492): 65-66. http://dx.doi.org/10.1038/371065a0.

Trindade MB, Lins-e-Silva ACB, Silva HP, Filgueira SB, Schessl M. Fragmentation of the Atlantic Rainforest in the Northern Coastal Region of Pernambuco, Brazil: recent changes and implications for conservation. Bioremediation. Biodiversity and Bioavailability 2008; 2(1): 5-13.

Welden CW, Hewett SW, Hubbell SP, Foster RB. Sapling survival, growth, and recruitment: relationship to canopy height in a Neotropical forest. Ecology 1991; 72(1): 35-50. http://dx.doi.org/10.2307/1938900.

Zar JH. Biostatistical analysis. 4th ed. New Jersey: PrenticeHall; 1999. 